\title{
Problems of Active Dynamic Thermography Measurement Standardization in Medicine
}

\author{
Antoni Nowakowski \\ Gdańsk University of Technology, Department of Biomedical Engineering, 11/12 Gabriela Narutowicza Street, 80-233 Gdańsk, Poland
}

\begin{abstract}
Reliability of thermographic diagnostics in medicine is an important practical problem. In the field of static thermography, a great deal of effort has been made to define the conditions for thermographic measurements, which is now the golden standard for such research. In recent years, there are more and more reports on dynamic tests with external stimulation, such as Active Dynamic Thermography, Thermographic Signal Reconstruction or Thermal Tomography. The subject of this report is a discussion of the problems of standardization of dynamic tests, the choice of the method of thermal stimulation and the conditions determining the credibility of such tests in medical diagnostics. Typical methods of thermal stimulation are discussed, problems concerning accuracy and control of resulting distributions of temperature are commented. The best practices to get reliable conditions of measurements are summarized.
\end{abstract}

\section{Introduction}

Infrared thermography has been used in medical diagnostics since the 1960s [1]. Its introduction to medical diagnostics aroused real enthusiasm as a non-contact and completely non-invasive method. However, after its initial success, it was subjected to severe criticism, because in the research and treatment of breast cancer it turned out that the method led to the false positive breast cancer diagnoses in the USA, which resulted in many unnecessary breast resections and, of course, great costs of damages, after lawsuits brought about by injured patients. Only after ca forty years, the introduction of new infrared imaging technologies and the commencement of work on standardization of research, there was an increase in interest in infrared diagnostics and a slow return to clinical trials, especially as a low-cost screening method. At the same time, since the nineties, technical methods of non-destructive infrared thermal imaging (NDTE) [2] have been developed, based on thermal models of the studied structures. Since the beginning of the $21^{\text {st }}$ century, these methods have also been used in medical diagnostics, known as Active Dynamic Thermography - ADT, Thermographic Signal Reconstruction-TSR, or Thermal Tomography - TT [3-5]. There are no agreed conditions for conducting such tests in terms of the applied thermal stimulation, which is the subject of this publication.

Autor korespondujący:

Antoni Nowakowski, nowakowski05@gmail.com

Artykuł recenzowany

nadesłany 12.07.2021 r., przyjęty do druku 05.08.2021 r

\section{Status of standardization works on thermal imaging in medical diagnostics}

Defining and agreeing on the conditions of thermal research in medical diagnostics took several decades and led to the creation of so-called the golden standard [6, 7], which includes:

- determining the conditions for preparing the patient for the tests - he or she should avoid taking stimulants and medications before the tests and taking up physical activities leading to the stimulation of the organism; the skin in the area of interest should be free from ointments, creams, etc.; a patient should be in the waiting or examination room at least 15 minutes before the test to stabilize the thermal conditions; areas of interest should be exposed during this time to achieve thermodynamic equilibrium;

- specification of the technical conditions of the diagnostic equipment - the type of an infrared camera, the geometric resolution of the lens used, the thermal resolution of the measurement - at least $0.1 \mathrm{~K}$; the position of a camera - perpendicular location, at least $0.5 \mathrm{~m}$ from the field of interest; scan frequency (the number of images recorded in a given period of time);

- determination of climatic conditions - a test room temperature $18-23{ }^{\circ} \mathrm{C}\left(\max .25{ }^{\circ} \mathrm{C}\right)$, stabilized with an accuracy not worse than $1{ }^{\circ} \mathrm{C}$; no ventilation and radiation sources and heaters that could affect the temperature of the examined areas of the patient's body; constant and controlled humidity in the room;

- databases and catalog of items of particular areas of interest of the patient's body ROI were developed determining the conditions for storing and processing medical images [8]; unfortunately, the DICOM standard for thermal imaging has not yet been implemented!

So far, no agreed guidelines have been defined in the diagnosis of a patient after using external thermal stimulation and analy- 
sis of resulting transient processes. Thus, people using dynamic thermography methods practically apply developed diagnostic instrumentation and algorithms, obtain "some" results, but there are no agreed procedures allowing for reliable assessment of the applied approach.

Theoretically, the problem comes down to the identification of parameters of the equivalent thermal model of a tested object defined at the Region of Interest - ROI. This was described in detail in the study of technical structures [2] and for some medical cases in [3-5]. Unfortunately, in medical diagnostics the problem is rather difficult, as the examined structures are complex and poorly defined; access to ROI is unilateral for measurements and excitation; the initial and boundary conditions necessary for solving the reconstruction procedures of equivalent thermal model parameters are usually unknown and additionally masked by biofeedback processes.

\section{Theory}

This problem is addressed anywhere, here basic information is taken from [5]. Thermal diagnostics requires analysis of thermal processes based on thermal models in correlation with physiological processes. Solution of so-called direct problem, determination of temperature distribution in time and space for assumed boundary conditions and known model parameters is possible for external thermal excitation. Having proper model one can compare the results of experiments and may try to solve the reverse problem. This responds to the question - what is the distribution of thermal properties in internal structure of a human body? Such knowledge may be directly used in clinical diagnostics if correlation of thermal and physiological properties is high.

In biologic applications the direct problem requires solution of the heat flow in 3D space; the analysis is most frequently based on the Pennes [8] „biologic heat flow equation”:

$$
c_{p} \rho \frac{\partial T(x, y, z, t)}{\partial t}=k \nabla^{2} T(x, y, z, t)+q_{b}+q_{m}+q_{e x}
$$

where: $T(x, y, z, t)$ - temperature distribution $[\mathrm{K}]$ at the moment $t[\mathrm{~s}] ; k$ - thermal conductivity $\left[\mathrm{Wm}^{-1} \mathrm{~K}^{-1}\right] ; c_{p}$ - specific heat $\left[\mathrm{J} \cdot \mathrm{kg}^{-1} \mathrm{~K}^{-1}\right] ; \rho$ - material (tissue) density $\left[\mathrm{kg} \cdot \mathrm{m}^{-3}\right] ; q_{b}\left[\mathrm{~W} \cdot \mathrm{m}^{-3}\right]$ - heat power density delivered or dissipated by blood; $q_{m}$ heat power density delivered by metabolism; $q_{e x}$ - heat power density delivered by external sources.

Generally, there are three approaches in analysis and solving of heat transfers to find distribution of temperature. The first one is analytic, known only for very simple structures of well define shapes, applicable in practice to get some estimates only. The second option is using numerical methods, usually based on FEM (finite element method). There are several commercial software packages broadly known and used for solving problems of heat flows, usually combining a mechanical part, including generator of a model mesh as well as modules solving specific thermal problems, as e.g., general mathematical programs MATLAB or Mathematica. FEM methods allow solution of $3 \mathrm{D}$ heat flow problems in time. Functional variability of thermal properties and non-linear parametric description of tested objects may be easily taken into consideration. Unfortunately, there are basic limitations concerning the dimension of a problem to be solved (complexity and number of model elements), which should be taken into account from the point of view of the computational costs. The third solution, most practical is a)

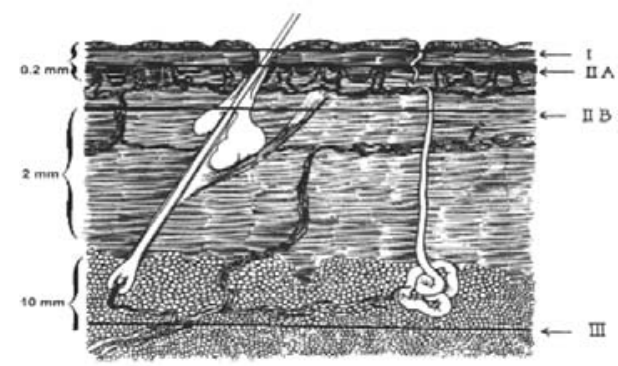

b)

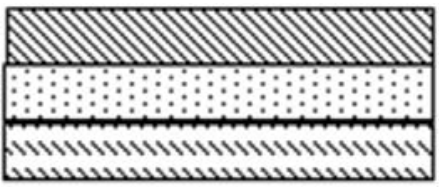

1 - Epidermis, 2 - Corium, 3 - Subcutaneous

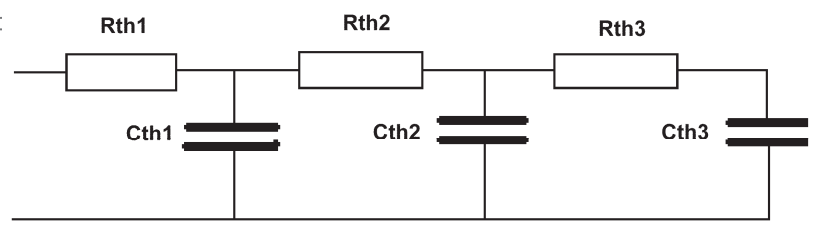

layer 1

layer 2

layer 3

Fig. 1. a) Anatomy of the skin [10] - depth of burn, b) three-layer structural model, c) equivalent thermo-electric model Rys. 1. a) Anatomia skóry [10] - głębokość oparzenia, b) trzy warstwy strukturalnego modelu termicznego - naskórek, skóra właściwa, warstwa podskórna, c) zastępczy model termo-elektryczny

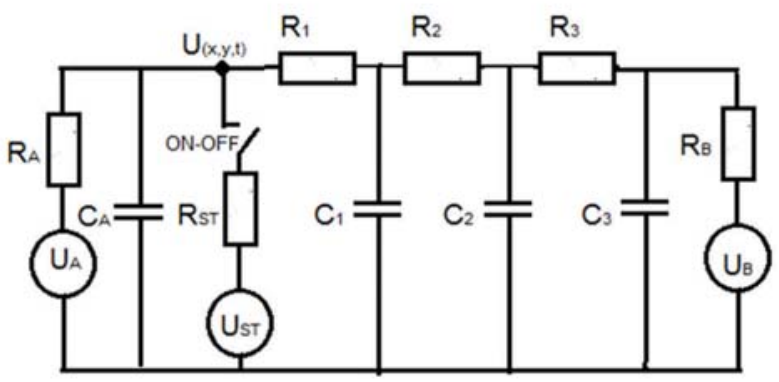

Fig. 2. Electric circuit simulating thermal processes at the ROI surface, where $U(x, y, t)$ voltage of a temperature value at a pixel $x, y$ in time $t ; \quad U$ - voltage sources representing ambient $A$, stimulation $\mathrm{ST}$ and body $\mathrm{B}$ temperature (boundary conditions), $\mathbf{R} \mathbf{i}$ - thermal resistances, $\mathrm{Ci}$ - thermal capacitances

Rys. 2. Zastępczy obwód elektryczny symulujący procesy termiczne na badanej powierzchni, gdzie $\mathrm{U}(\mathrm{x}, \mathrm{y}, \mathrm{t})$ napięcie o wartości temperatury wybranego piksela $x$, y w momencie $t$; $A$ - otoczenie o temperaturze $U_{A}$, oporności termicznej $R_{A}$ i pojemności termicznej $C_{A} ; U_{S T}-$ źródło pobudzenia cieplnego o temperaturze i rezystancji termicznej $R_{S T}$ trzywarstwowy model skóry $R_{i} C_{i} i$ źródło temperatury wewnętrznej ciała $U_{B}$ o rezystancji termicznej $R_{B}$

the use of equivalent electro-thermal models, as in Fig. 1 for skin burn as an example [5].

In medical diagnostics the practical question is solution of the reverse problem - reconstruction of model parameters. There are several conditions necessary for getting reliable results, what is here discussed for the model of the skin as an example (Fig. 2).

It should be underline, that for normal static thermography in equilibrium the surface temperature distribution $T_{(x, y, 0)}=U_{(x, y, 0)}$ depends only on boundary ambient temperature $U_{\mathrm{A}}^{(\mathrm{x}, \mathrm{y}, 0)}$ (typically around $20{ }^{\circ} \mathrm{C}$ ), internal body temperature $U_{\mathrm{B}}$ (typically around $37^{\circ} \mathrm{C}$ ), tissue properties distribution represented by nonlinear thermal resistances, and heat exchange conditions with environment (ambient) represented by $R_{\mathrm{A}}-$ combining radiation heat 
exchange and air conduction. In fact, this situation is recorded by static thermography and interpreted in medical diagnostics.

Use of the stimulation source $U_{\mathrm{ST}}$ allows to record thermal transiens represented by series of thermograms in time $U(x, y, t)$ and reconstruct thermal capacitances and components of thermal resistances $C_{\mathrm{i}}$ and $R_{\mathrm{i}}$. It should be underline, that while the excitation source is on and off the structure of the circuit is modified, resulting in different heat flows. Additionally, heating and cooling are changing boundary conditions and even structure parameters (e.g., thermal model dimensions) as the depth of heat penetration depends on the duration time of excitation.

There are several methods of reconstructing the parameters of an equivalent thermal model after using external stimulations. Such procedures are described in more detail in the cited literature $[3-5]$. One of the first questions is heating or cooling? Another concern the shape of the stimulation and its parameters, duration or amplitude. In addition, there are a number of limitations with respect to patient safety and the reliability of the thermal response, due to existing physiological biological feedback mechanisms. The methods of identifying simple two or three-layer models represented by ADT and TSR parametric images are relatively easy reconstructed.

The most frequently reconstructed are parameters of the equivalent exponential equation. The parameters to be determined are: constant temperature component $T(x, y)=T(x, y, 0)$ - temperature in steady state; coefficients representing increases or decreases of the temperature $T$ and thermal time constants $\tau$. On this basis, the examined tissue can be quantitatively described by means of time constants and exponential terms

$$
T(x, y, t)=T(x, y)_{s}+\sum_{j=1}^{m} T(x, y)_{j} \cdot\left[-e^{\frac{-t}{\tau(x, y)_{j}}}\right]
$$

for the natural heating phase after switching off the cooling apparatus. The natural cooling phase after switching off the heating stimulation source is described by very similar equation (3) - note lack of the sign minus in the last component:

$$
T(x, y, t)=T(x, y)_{s}+\sum_{j=1}^{m} T(x, y)_{j} \cdot\left[e^{\frac{-t}{\tau(x, y)_{j}}}\right]
$$

where: $T(x, y, t)$ - temperature of the pixel $(x, y)$ for the time $t$; $\Delta T(x, y)_{j}$ - values of temperature changes caused by the excitation stimulus, time constants $\tau(x, y)_{j}$

Formally both equations are described by the same symbols, but practically values of the parameters are different as heat flows are different for cooling and for heating, for both the excitation phase and for the recovery to equilibrium phase!

Practically temperature transients at ROI are registered with limited accuracy and reconstruction of tested structure parameters based on series of thermographic images are limited. For a sufficient compliance of the model with the measured data, very often only two exponential components are determined, i.e. $m=2$.

The obtained measurement data from the thermographic camera is fitted to the exponential models described by the above equations using simplex, Levenberg-Marquardt or other matching algorithms (minimizing error functions). To improve the quality of fit to the replacement model, low-pass or median filtering can be used.

Similarly, transient changes on the tissue surface can be characterized by the TSR (Thermographic Signal Reconstruction) method. The method assumes that the temperature changes for the area without defects should be consistent with the one-dimensional Fourier heat flow equation, and that the area above the defect will have deviations from this course. One can write the Fourier equation in the logarithmic domain [11] as:

$$
\ln [\Delta T(x, y, t)]=\ln \left(\frac{Q}{e}\right)-\frac{1}{2} \ln (\pi \cdot t)
$$

where: $Q$ - heat power density, $e$ - effusivity.

For the data space transformed in this way, one may adjust the data to the $n$-degree polynomial:

$$
\begin{aligned}
\ln [\Delta T(x, y, t)]=a_{0} & +a_{1} \ln [T(x, y, t)]+a_{2} \ln ^{2}[T(x, y, t)]+\ldots \\
& +a_{n} \ln ^{n}[T(x, y, t)]
\end{aligned}
$$

where: $a_{i}$ - coefficients of the polynomial, $n$ - order of the polynomial, $T$ - temperature, $t$ - time.

Typically, the order of the polynomial is $4-5$. As the last step of the procedure, the first and second derivatives of the parameter changes after time are determined.

One practical problem should be underline in pulse thermography - the choice of excitation time should be carefully analysed! The simplest model of heat penetration shows, that so called heat diffusion length $L$ is a function of material properties ( $\alpha$ - tissue diffusivity) and time $t$,

$$
L=2(\alpha t)^{1 / 2}
$$

what means that the excitation time should be chosen according to expected model depths, on the other hand this means, that equivalent thermal model may be changed with time excitation!

\section{Practice}

The general concept of measurements performed in ADT, TT, TSR is shown in Fig. 3. First, steady state temperature distribution on the tested surface (ROI) is registered using the IR camera. The following step requires thermal excitation application to the diagnosed ROI and registration of temperature transients at the ROI surface, especially after switching off the excitation. An external thermal excitation source (heating or cooling) should be applied to a tested structure in fully controlled conditions.

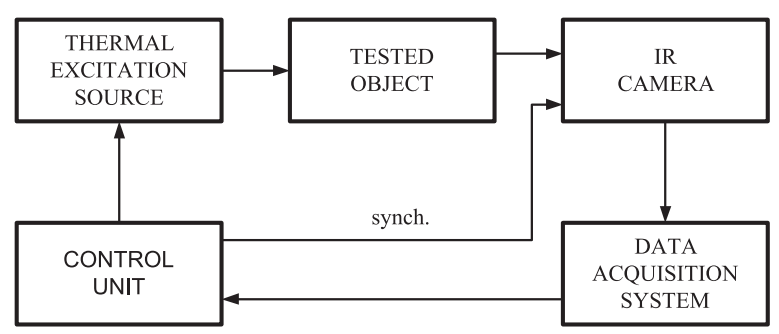

Fig. 3. Block diagram of basic ADT/TSR/TT measurement procedure Rys. 3. Schemat blokowy pomiaru w ADT, TSR i TT

The control unit synchronizes the processes of excitation and registration. For pulsed excitation diagnostic measurements should be performed at the recovery phase to initial conditions after excitation is off. All data are stored in the Data Acquisition System for further computer analysis and model parameters determination.

As in medicine one is dealing with living patients' problems of unintentional movements, breezing etc. must be solved. This requires synchronization of following images, determination of the region of interest the same on all images in the series, even if the data are taken in different days, e.g., when studying wound healing processes; corrections of camera unintentional movement etc. 
Much more complicated is procedure of thermal tomography as in this case dimensions and material properties of $2 \mathrm{D}$ or $3 \mathrm{D}$ structural thermal models must be reconstructed. Typical tomography procedure of model parameter reconstruction is shown in Fig. 4. Thermal excitation (from a physical source as well as simulated for the assumed thermal model) is applied simultaneously to the tested structure and to its model. As the result thermal transients are registered at the surface of the object by the IR camera. In parallel the same process should be simulated for the model. For each pixel the registered temperature course is identified. The measurement results are compared with the simulated transient and if necessary, the thermal model is modified in iterative procedure to fit to experimental results. If the results of measurements and simulation are convergent the reconstruction procedure stops. With a great probability the model is representing the tested structure.

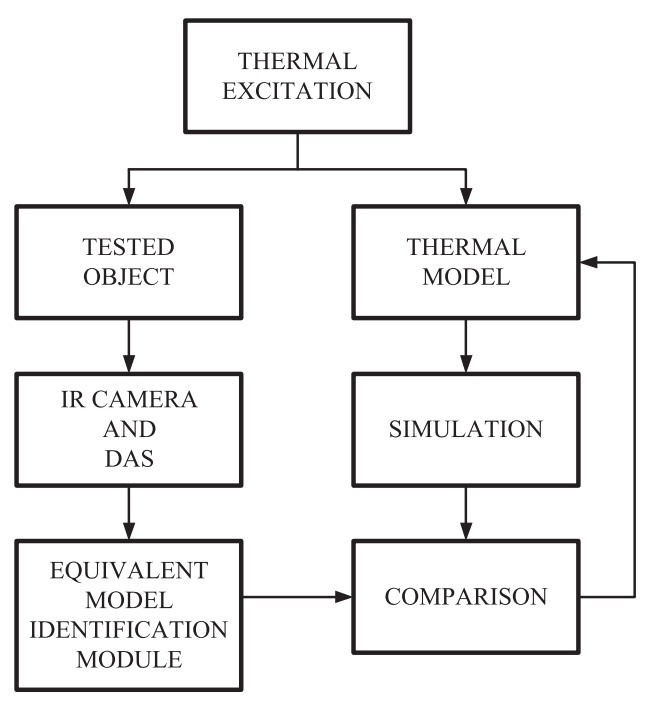

Fig. 4. Thermal Tomography procedure for reconstruction of a tested structure properties

Rys. 4. Algorytm rekonstrukcji parametrów badanej struktury w procedurze tomografii termicznej

Unfortunately, this reconstruction procedure is rather long and not always successful as the problem is mathematically ill posed and boundary conditions are not always properly identified.

Dynamic measurements with excitation are performed in a system, as for example shown in Fig. 5. This is the block diagram of the measurement system for tests using the method of active dynamic thermography. The system consists of a central computer (1), a controller (2), a symmetrical thermal excitation system (3), a thermographic camera (4) and the RGB camera (5). The whole operation of the system is controlled by a computer with a program of the sequence of excitation signals and the software for the acquisition of RGB image data and thermographic sequences. The adjustment of the control signals takes place in the controller (2), which is responsible for obtaining the voltage levels and ensuring the I/O current efficiency necessary to actuate the cryotherapy devices.

The examined object (6), in this case a cardiac surgery patient, is located about one meter from the stimulating and recording set. During the examination, the patient usually lies in the bed with the area of interest exposed, e.g., the chest. Access to the patient is limited to the study of the surface of the examined ROI, unilaterally, both for the data acquisition system and the sources of excitation. To read more about this set see $[4,12]$, where also issues related to applied software, data processing, model fitting, normalizing to the reference ROI are discussed.
Usually, diagnostic instrumentation is equipped in proper software packages allowing easy manipulation and at least semiautomatic registration of images and data manipulation. ADT requirements are not easy as the simplest descriptive multi exponential models are applied. As the diagnostic descriptor mainly thermal time constants $\left(\tau_{1}, \tau_{2}\right)$ are applied though the magnitude $T_{s}$ (temperature gradients) are also of important diagnostic value. Such descriptors are strongly correlated to thermal equivalent model, e.g., the 3-layer structure described by thermal resistance $\boldsymbol{R}_{t h(1-3)}$ and thermal capacitance $\boldsymbol{C}_{t h(1-3)}$. The product $\boldsymbol{R}_{t h(1-3)} \boldsymbol{C}_{t h(1-3)}$ is equivalent to thermal time constants.

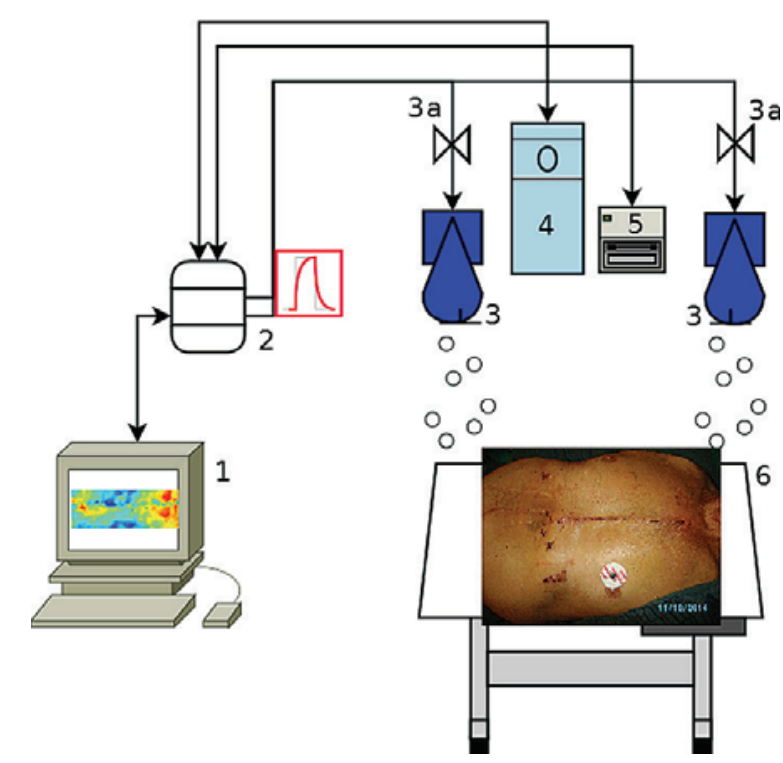

Fig. 5. Block diagram of the stand for research with the method of active dynamic thermography

Rys. 5. Schemat blokowy stanowiska do badań metodą aktywnej termografii dynamicznej

The technical solutions of the system may vary. The use of double vision and thermographic cameras enables the acquisition of stereovision images, which is used in special, non-standard solutions in medical diagnostics. A separate challenge is the source of thermal stimulation. Here, a stimulation source was used in the form of two devices for cold air cryotherapy, controlled by electro-valves (3a). This solution allows for cooling of the ROI more uniformly than in the case of using a single device. Alternatively, the tested surface may be cooled with a mixture of $\mathrm{CO}_{2}$ and air from another cryotherapy unit, which may be applied as the cooling source. In this case we get positive experience as diagnostically valid measurements were taken after switching off the coolers, what takes less than one second. In some applications the source of heating with a set of infrared lamps can also be used to stimulate ROI. Other technical solutions may be based on contact cooling, but also laser or microwave heating; vibrothermography is known for NDTE. The mentioned methods have a number of limitations related to properties of energy absorption by biological tissues.

In the case of non-contact stimulation, the temperature reading is synchronized with turning the thermal source on and off, so that the tissue stimulation phase and the response phase are separate from each other. In the case of a human examination, the stimulation must be of a safe value, i.e., not to damage the tissues or cause pain.

The result of the system's operation is the acquisition of a series of thermographic images, which in the next stage are subjected to procedures specific for each method of reconstructing the parameters of the thermal equivalent model of the tested object. 


\section{Discussion}

Let us pay attention to the possibility of an unequivocal answer to a number of questions that determine the credibility of each of the above-mentioned measurement possibilities and the reconstruction of parametric images. Known methods of identifying parameters of electrical circuits in technical diagnostics may be used as a reference, however, it is necessary to remember what limitations are introduced by thermal examination of living organisms.

1. Selection of the stimulation amplitude - the problem in practice concerns the patient's safety! Resulting temperature should remain in the range slightly above zero degrees Celsius, so as not to damage the tissue by freezing, and not exceeding the temperature of $42{ }^{\circ} \mathrm{C}$ when the tissue is denatured. Keeping in mind the gold standard of static thermographic testing, when the patient is prepared for testing under stable thermodynamic conditions, the ROI surface temperature is typically $30-34{ }^{\circ} \mathrm{C}$. Thus, the amplitude of the excitation during heating must not exceed about $8{ }^{\circ} \mathrm{C}$. In the case of cooling, the excitation range may be greater, to about minus $30{ }^{\circ} \mathrm{C}$ from the initial, but in practice this value should be reduced by half, to about $15{ }^{\circ} \mathrm{C}$, which will be justified in the point 4 . Obviously, the greater excitation amplitude allows measurements to be made with better accuracy taking into account limited resolution of a thermographic camera, usually $0.1-0.02{ }^{\circ} \mathrm{C}$. This discussion indicates the advantage of cooling!

2. Signal shape selection - sinusoidal, pulsed, shape projected? Each of these proposals allows for the differentiation of characteristic features of the response signals and the diagnosis of "something", but again it is worth remembering about the physiology. In the technology - NDTE and NDE - theoretically the most accurate results of the identification of an electric circuit property are given by the analysis of excitation with a sinusoidal signal. The question is whether this also applies to living organisms? Therefore, what frequency range of thermal signals should be considered? In practice, these are rather low frequencies, single and fractions of Hz. Measurements at low frequencies must be performed carefully, because there exist biological feedback phenomena, including the so-called vasoconstriction and vasodilation, i.e., contraction and relaxation of smooth muscles in the wall of blood vessels as a result of cooling or heating. These phenomena are characteristic to all warm-blooded animals! Frequency analysis is thorough but time consuming. Additionally, there is a factor of movement instability, e.g., related to breathing; what means that thermographic images require position correction. For these reasons, the frequency method is not recommended in practice. Dirac pulse-shaped excitation is an attractive solution, but due to p.1 it does not give the possibility of obtaining a sufficiently strong thermal signal. The shape projected signals have been applied successfully in technology, e.g., in electronic circuit boards testing, but so far have not been used in medical thermal diagnostics. In practice, the rectangular pulse-shaped excitation is most often used for both heating and cooling in medical applications allowing sufficient changes of temperature. Still, there is the problem of duration of such stimulation. The problem is not trivial, because the longer the excitation time, the deeper heat penetrates the ROI area, which changes the measurement conditions and parameters of the thermal equivalent model!

3. Heating or cooling? Already the reply to point 1 shows the advantage of cooling, but it is not the only argument. Note that under the conditions of thermodynamic equilibrium there is a temperature gradient in the layer of the subsur- face tissue, from $30-34{ }^{\circ} \mathrm{C}$ to about $37{ }^{\circ} \mathrm{C}$ in depth of the body. This means that heating causes an increase in the temperature of the body surface, thus reducing the temperature gradient in the near-surface layer, and consequently reducing the heat flows inside the body! In contrast, cooling increases the temperature gradient, which increases heat transfer and improves thermal contrast. This causes stronger heat exchange within tested structure giving more reliable data for tissue parameters reconstruction!

4. Determination of reliable boundary conditions for the reconstruction of model parameters. It is worth to determine the duration of the heating/cooling stimulus to limit the thickness of the analyzed ROI layer to diagnostically interesting value. When cooling, it is recommended to obtain at the end of excitation the surface temperature at the level of the ambient temperature. This eliminates heat exchange at the tested surface and forces heat transfer within internal tissue layers, at least at the initial phase of recovery to the equilibrium conditions after thermal excitation.

\section{Conclusion}

According to analysis of the circuit in Fig. 2 there are several cases of heat flows resulting in static and dynamic temperature distributions important for diagnostics in medicine. The most important for diagnostics are added value strong heat flows via biological structures. This leads to advice to use cooling as the privileged solution. Heating is more difficult in control of safety conditions and additionally leads to flat temperature distribution inside the body what means lower heat flows and increase of the role of heat exchange with the environment, what is of rather low diagnostic importance.

In medical diagnostics of ADT, TSR and TT it is postulated to use cooling in the form of a rectangular stimulus with a duration that ensures obtaining the ROI surface temperature equal to the ambient temperature, which standardizes the initial boundary conditions. As a result, the process of returning to thermodynamic equilibrium conditions is dominated by heat flows inside the tested ROI, so the reconstruction result allows for a reliable assessment of the parameters of the layers of the substitute thermal model. In the exemplary solution shown in Fig. 5, the thermographic camera can be used to automatically determine the moment of stopping the excitation signal, here the cooling process. On the other hand, cooling to lower than ambient temperatures are resulting in bigger temperature gradients what with limited thermal resolution of applied thermal camera always improves measurement accuracy, while heat exchange with ambient is not decreasing diagnostic information given by heat flows inside the ROI.

There is still the problem of the excitation pulse duration. It may be relatively easy to reach ROI surface temperature equal to the ambient temperature and keep this value for longer what in result may increase the tissue layer of this temperature. This may be changing in not fully controlled way boundary condition for the recovery phase after switching the excitation off. Probably this should be worked up for different diagnostic applications.

\section{References}

1. Diakides M., Bronzino J., Peterson D. (eds.), Medical Infrared Imaging: Principles and Practices, CRC Press, 2012.

2. Maldague X., Theory and Practice of Infrared Technology for Non-Destructive Testing, J. Wiley \& Sons, Inc., New York 2001. 
3. Chmielewski L., Kulikowski J.L., Nowakowski A., Biocybernetyka i Inżynieria Biomedyczna 2000, Vol. 8, Obrazowanie biomedyczne, 14, Nowakowski A., Wróbel Z. (ed.), Termografia podczerwieni w diagnostyce medycznej, 475-614; Vol. 15, Nowakowski A., Kaczmarek M., Hryciuk M., Tomografia termiczna, 615-696, AOW EXIT, 2003.

4. Kaczmarek M., Nowakowski A., Active IR-Thermal Imaging in Medicine, "Journal of Nondestructive Evaluation", Vol. 35, No. 19, Springer, DOI 10.1007/s10921-016-0335-y, 2016

5. Nowakowski A., Quantitative Active Dynamic Thermal Imaging and Thermal Tomography in Medical Diagnostics [In:] Diakides N., Bronzino J. (ed.), Medical Infrared Imaging, CRC, 2008

6. Ammer K., Ring F.E., Standard Procedures for Infrared Imaging in Medicine, 22.1-22.14, [In:] Diakides N., Brozino J.D., ed., Medical Infrared Imaging, CRC Press, 2008.

7. IEC/ISO. IEC 80601-2-59: Particular requirements for the basic safety and essential performance of screening thermographs for human febrile temperature screening. Geneva, Switzerland: International Electrotechnical Commission (IEC)/International Organization for Standardization (ISO); 2017.
8. Schaefer G., Storage and Retrieval of Medical Thermograms, 23.1-23.15, [In:] Diakides N., Brozino J.D., ed., Medical Infrared Imaging, CRC Press, 2008.

9. Pennes H.H., Analysis of tissue and arterial blood temperatures in the resting human forearm, "Journal of Applied Physiology", No. 1, 1948, 93-122,

DOI: $10.1152 /$ jappl.1948.1.2.93.

10. Eberhart C., Heat transfer in medicine and biology, Analysis and applications, Vol. 1, Plenum Press, London, 1985.

11. Balageas D.L., Roche J.M., Leroy F.H., Liu W.M., Gorbach A.M., The thermographic signal reconstruction method: a powerful tool for the enhancement of transient thermographic images, "Biocybernetics and Biomedical Engineering", Vol. 35, No. 1, 2015, 1-9, DOI: 10.1016/j.bbe.2014.07.002.

12. Kaczmarek M., Nowakowski A., Aktywna Termografia Dynamiczna - przetwarzanie serii obrazów w diagnostyce medycznej, [In:] Nowakowski A.Z., Kaczmarek M., Królicki L., Kulikowski J.L. ed.: Inżynieria biomedyczna - podstawy i zastosowania, Vol. 8, 479-504, Obrazowanie biomedyczne, AOW EXIT, 2020.

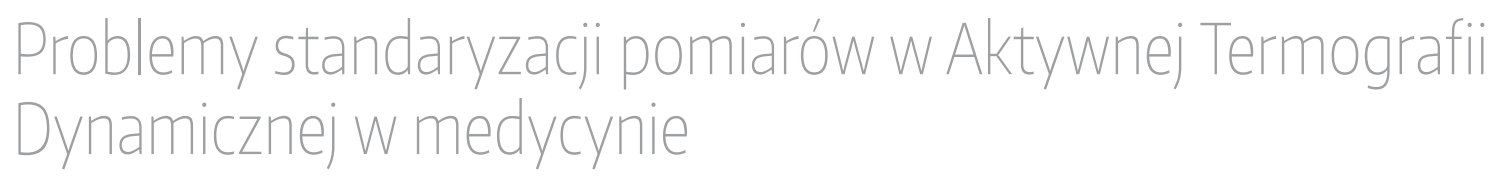

Streszczenie: Wiarygodność diagnostyki termograficznej w medycynie stanowi ważny problem praktyczny. W zakresie statycznej termografii w podczerwieni włożono sporo wysiłku, by zdefiniować warunki pomiarów termograficznych, co stanowi obecnie złoty standard takich badań. W ostatnich latach pojawia się coraz więcej doniesień dotyczących badań dynamicznych z pobudzeniem zewnętrznym, takich jak ADT, TSR czy tomografia termiczna. Przedmiotem niniejszego doniesienia jest dyskusja problemów standaryzacji badań dynamicznych, wyboru sposobu pobudzenia termicznego i warunków decydujących o wiarygodności takich badań w diagnostyce medycznej.

Słowa kluczowe: aktywna termografia dynamiczna, rekonstrukcja sygnału termograficznego, tomografia termiczna, dynamiczne testy termiczne, standaryzacja

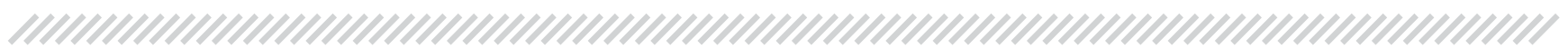

\section{Prof. Antoni Nowakowski, PhD, DSc}

nowakowski05@gmail.com

ORCID: 0000-0001-6116-498X

MSc EE Biomedical Eng. Warsaw University of Technology 1967, PhD 1973, DSc 1985, full professor at the Technical University of Gdańsk, founder and former head of the Department of Biomedical Engineering. Research - measurements and data acquisition systems; modelling and simulation, non-invasive medical diagnostics,

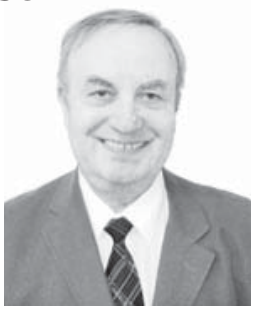

visualisation and reconstruction methods, passive and active thermography in medicine; use of informatics and telematics in research and education. 